\title{
抗ウイルス剂開発のための新しい試み
}

\author{
下村徹 - 大橋 祐子

\section{A NEW APPROACH TO EXPLOITATION OF ANTIVIRAL SUBSTANCES}

\author{
Toru SHIMOMURA and Yuko OHASHI \\ Institute for Plant Virus Research, Chiba City
}

[受付 2 月28日，1972年]

タバコ・モザイク・ウイルス (TMV) の local lesion host であるグルチノーザまたはキサンチ nc タバコなど では，TMVを接種した葉に local lesion が形成され る. 各 lesion の大きさはウイルスの増殖と共に漸次拡 大するが，ウイルスの增殖または移行の速度は, systemic host であるキサンチタバコでのそれに比べるとか なり遅(1)6)。したがつて，一般に local lesion host は ウイルスに抵抗性で, systemic host は罹病性であると 考えられている. しかし, systemic host の場合でも, ウイルスを接種した葉を熱または冷処理することによつ てこの葉に local lesion を形成させ得ることは既報1227) の通りである. Systemic host にも local lesion の形成 能はあるが，その発現が普通は抑制されていて，これら の処理を受けると, 抑制が解かれて lesion が形成され るのではないかと考えられる。

以上のようにウイルスに感染した systemic host の葉 を熱または冷処理など物理的処理をすることによつてこ の葉に lesion が形成されるならば，薬剤施用などの化 学的处理によつて lesion が形成される場合もあるので はないかと考えられる、筆者らの最近の試騟結果3)によ ると, 切り取つたウイルス接種葉の葉柄からアクチノマ イシンDまたはクロモマイシン $\mathrm{A}_{3}{ }^{8)}$ の溶液を吸わせるこ とによつて, 実際にこの葉に lesion を形成させ得るこ とが明らかであつた，以上の事実から， ウイルスに感染 した systemic host の葉に楽剤を散布して感染部に lesion 形成させて, ウイルスをこの部分に局在化させる ことも可能となるであろう.この場合, 薬剤を散布した 葉でのウイルスの移行が抑制されるのかどうか，たとえ ば lesion 形成によつて local lesion host そ生ずるといか

植物ウイルス研究所

本研究の一部は文部省科学研究費(総合研究) によつて 行なつた,
れている獲得抵抗性 (acquired resistance) 4.5 )が得られ るのかどらか, 形成された lesion 部にウイルスが封じ こめられることがあるのかどらかなどが問題となる。し かし，、ずれにせよ薬剤の施用によつて感染部に lesion が形成され，この葉での以後のウイルスの増殖または移 行が妨げられることがあるとすれば，このような薬剤は ウイルス防除の観点からは一種の抗ウイルス剤として考 えられてよいであるう。

防除の観点から考えると，なるべく多くのウイルスと その systemic host の組合わせで，処理により lesion が形成されることが望ましい．熱または冷処理の場合は 既報1,2,7)の方法で試験を行なつたところ，第 1 表㐳示す ように，多くのウイルスと宿主の組合わせで lesion が 形成されることが明らかとなつた．アクチノマイシンD の場合はつぎの方法で試験を行なつた．すなわち，葉に ウイルスを接種してから $1 \sim 2$ 日後，切り取つた葉の葉 柄からその $200 \mathrm{r} / \mathrm{ml}$ の溶液 $0.25 \sim 0.5 \mathrm{ml}$ を完全に吸わ せた後容器に水を加えてそのまま，または切取葉をぺ トリ皿内に納めて, これらを陽光定温器内に保ち, lesion 形成の有無を調べた．熱または冷処理の場合と同 じく, 第 1 表のように数種のウイルスと宿主の組合わせ で lesion が形成されることが明らかであつた（第 1 表 に注 $30^{\circ} \mathrm{C}$ で TMV に全身感染した local lesion host の場合も含めた).

また，防除の観点からは薬風の散布によつて lesion が形成されることが望ましい，最初の段階として，キ步 ンチタバコ(草丈約 $15 \mathrm{~cm})$ の葉の一部に TMV $(10 \gamma / \mathrm{ml})$ を接種し， $25^{\circ} \mathrm{C}$ に 2 日間保つた後，接種部を中心にし て無接種部に及ぶ部分にアクチノマイシンD（50 100 $\gamma / \mathrm{ml})$ またはクロモマイシン $\mathrm{A}_{3}(500 \gamma / \mathrm{ml})$ を注射器で 注入して再び $25^{\circ} \mathrm{C}$ に保ち, 接種部に lesion が形成さ れるかどうかを観察した，その結果，注入 1 日後接種部 のみにリング状の lesion が形成され，注入した部分の 
Table 1 Local lesion formation on virus-infected leaves treated by different temperatures or actinomycin $\mathrm{D}$

\begin{tabular}{|c|c|c|c|c|c|}
\hline \multirow{2}{*}{ Host plant } & \multirow{2}{*}{ Virus* } & \multirow{2}{*}{$\begin{array}{l}\text { Incuba- } \\
\text { tion } \\
\text { tempera- } \\
\text { ture }\left({ }^{\circ} \mathrm{C}\right)\end{array}$} & \multicolumn{3}{|c|}{ Treatment** } \\
\hline & & & $\begin{array}{l}\text { Actino- } \\
\text { mycin D }\end{array}$ & Heat & Cold \\
\hline \multirow{5}{*}{$\begin{array}{l}\text { Nicotiana } \\
\text { glutinosa }\end{array}$} & TMV-OM & 30 & $+* * *$ & + & + \\
\hline & -HR & 30 & + & + & + \\
\hline & $-\mathrm{L}$ & 30 & + & + & + \\
\hline & $\mathrm{CMV}$ & 23 & + & + & + \\
\hline & PVX & 23 & + & & + \\
\hline $\begin{array}{l}\text { N. tabacum, } \\
\text { "Xanthi nc" }\end{array}$ & TMV-OM & 30 & + & + & + \\
\hline \multirow{2}{*}{$\begin{array}{l}\text { N. tabacum } \\
\text { "Xanthi" }\end{array}$} & TMV-OM & 23 & + & + & + \\
\hline & PVX & 23 & & + & + \\
\hline \multirow{3}{*}{$\begin{array}{l}\text { N. tabacum } \\
\text { "Samsun" }\end{array}$} & TMV-OM & 23 & + & + & + \\
\hline & $\mathrm{CMV}$ & 23 & + & & \\
\hline & PVX & 23 & + & + & + \\
\hline \multirow{3}{*}{$\begin{array}{l}\text { Petunia } \\
\text { hybrida }\end{array}$} & TMV-OM & 23 & + & + & + \\
\hline & $\mathrm{CMV}$ & 23 & & + & \\
\hline & PVX & 23 & & + & + \\
\hline
\end{tabular}

* TMV : Tobacco mosaic virus ; OM : Common strain; HR: Holmes ribgrass strain; L : Tomato strain; CMV : Cucumber mosaic virus; PVX : Potato virus X

** The treatments were made on detached and virus-inoculated leaves after $2-3$ days incubation according to the methods previously described. 1).2).3).7)

*** Lesions formed.

無接種部にはどんな変化もみられなかつた（第 1 図). その後 lesion は拡大融合し，3 日後には薬液が注入さ れた無接種部の一部を含めて接種部が枯死するためかウ イルスは頂葉に移行しなかつた. ただしクロモマイシン $\mathrm{A}_{3}$ を注入した場合は, 約 10 日後頂葉にウイルス感染症 状に似た vein clearing・捩れなどの薬害を生じること があつた.つぎの段階として, 薬剤を散布する代わりに キサンチタバコの葉の TMV 接種部に, 接種 2 日後アク チノマイシンD $(200 \gamma / \mathrm{ml})$ またはクロモマイシン $\mathrm{A}_{3}(500$ $\gamma / \mathrm{ml})$ を塗布した場合について検討した. この場合は, 夏期 $\left(8 \sim 9\right.$ 月, $\left.25 \sim 30^{\circ} \mathrm{C}\right)$ の実験では 1 回の塗布でも 接種部に lesion が形成されたが, 冬期（11〜12月, 17 $\left.\sim 30^{\circ} \mathrm{C}\right)$ の実験では 2 日後に約 2 時間おきに $2 \sim 3$ 回塗 布することによつて lesion が形成された. しかし,こ れらの塗布試験では, 頂葉にウイルスが移行しない場合 と移行して頂葉にモザイク症状が出現する場合とがあつ た.

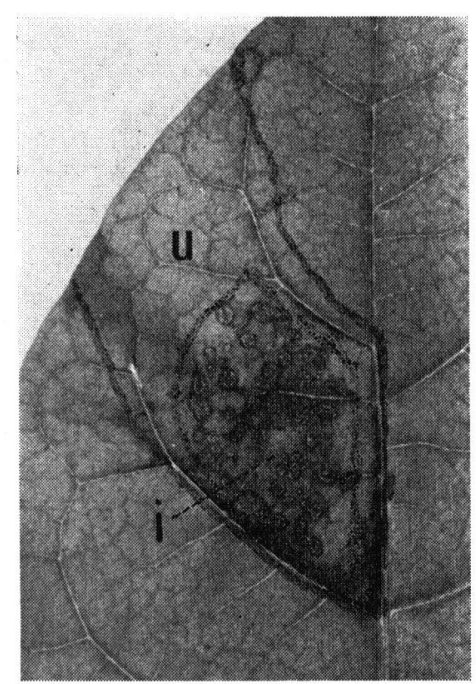

Fig. 1 Local lesions formed on "Xanthi " tobacco leaf. Actinomycin D was injected 2 days after inoculation with TMV. i : TMV-inoculated and actinomycin D -injected portion ; $\mathrm{u}$ : Uninoculated and actinomycin D -injected portion.

アクチノマイシンDまたはクロモマイシン $\mathrm{A}_{3}$ による lesion 形成の機構は明らかでないが，これらの薬剂が共 にDNA 依存 RNA 合成の阻害作用をもつことから，こ の作用に由来するのではないかとも考えられる．このよ らな作用は当然宿主の代謝に干渉して薬害を起こすが, この場合宿主には薬害を与えない濃度で感染部に lesion を形成するか, 薬剤施用後短時間でこの葉に lesion を 形成した後宿主の中ですみやかに分解するようなものが みつかれば，このような薬剤は抗ウイルス剂として有望 であろう。

植物ウイルスの増殖を抑制する物質について今までに 20年以上の研究が続けられてきたにもかかわらずなお実 用化されているものがない現状であるが, 以上に述べた ような lesion 誘起作用をもつ薬剤も抗ウイルス剤*の 開発上留意されてよいのではないかと考える.

稿を終えるにあたり，クロモマイシン $\mathrm{A}_{3}$ を供与され た武田薬品工業株式会社小野小三郎, 山本弘一両氏の御 厚志に感謝する.

\footnotetext{
*アクチノマイシンDとクロモマイシン $\mathrm{A}_{3}$ にはTMV の増殖を抑制する作用はない3). このような作用が なくとも終極的にはウイルスのまん延を阻止するよ うなものも，広い意味では抗ウイルス剤の範疇に入 れてよいのではないかと考えた。
} 


\section{文献}

1）大橋祐子, 下村 徹 (1971)：日植病報, 37, 22 .

2) 大橋祐子, 下村 徹 (1971) : 日植病報, 37, 211.

3) Ohashi, Y. and Shimomura, T.: Virology (印刷中).

4) Ross, A. F. (1961): Virology 14, 329.
5) Ross, A. F. (1961): Virology 14, 340.

6) Shimomura, T. (1971): Phytopath. Z., 70, 185.

7) Shimomura, T. and Ohashi, Y. (1971): Virology 43, 531.

8) Tatsuoka, S. et al. (1958) : Gann 49, suppl., 23. 